\title{
The Crucial Role of Local Governments in Setting up a Social Safety Net.
}

\section{Ding Kaijie}

\section{(2) OpenEdition}

12 Journals

Édition électronique

URL : http://journals.openedition.org/chinaperspectives/387

DOI : 10.4000/chinaperspectives.387

ISSN : 1996-4617

Éditeur

Centre d'étude français sur la Chine contemporaine

\section{Édition imprimée}

Date de publication : 1 août 2003

ISSN : 2070-3449

\section{Référence électronique}

Ding Kaijie, "The Crucial Role of Local Governments in Setting up a Social Safety Net. », China Perspectives [En ligne], 48 I july- august 2003, mis en ligne le 20 décembre 2006, consulté le 28 octobre 2019. URL : http://journals.openedition.org/chinaperspectives/387 ; DOI : 10.4000/ chinaperspectives.387

Ce document a été généré automatiquement le 28 octobre 2019.

(C) All rights reserved 


\title{
The Crucial Role of Local Governments in Setting up a Social Safety Net.
}

\author{
Ding Kaijie
}

1 Since launching its economic reforms and open-door policy, China has entered a phase of social transition that has given rise to many social problems. The establishment of a solid safety net by Chinese local governments is therefore a key component in maintaining social stability and essential for ensuring local economic growth.

2 In China, the "social safety net" (shehui anquan wang) refers in the main and in general to the social security system formed by all levels of government as a coherent governing body. Because the context of this social safety net is vast, it has as yet no rigorous construct in law and has not been the subject of policy-making or regulation. The conception of a "social security network" is certainly one part of the social safety net, with some scholars describing the social security system as a "social security network". The purpose of the net is to protect disadvantaged groups-the poor, women, children, the unemployed, the disabled, the aged, etc.

3 Local governments usually play an important role in the establishment of a social safety net, and this is a topic that is definitely worthy of discussion. The term "local government" covers a comprehensive variety of ideas, however, and the composition of local governments differs according to the level of administrative governance. In this article, we argue that "local government" is a conception relative to the central government, the remit of which stretches from provincial to township levels.

Anxiety during the transition

4 In its "Human development report: China" published in 1999, the United Nations pointed out that while China's market-oriented reforms and rapid economic growth had resolved some problems, they had also posed a variety of challenges. Among the most prominent of the social issues reported were "the growth of unemployment", "some people living in difficulties", "a number of poor people", "the growing proportion of ageing people", "unfavourable income redistribution", etc. Faced with 
this situation, the previous social insurance system has disintegrated, but a new, solid social security system has yet to come into being. Chinese local governments are thus located in what can be termed a "risk society", namely a transition society with many social problems.

5 In the following, we discuss six main social problems faced by local governments in this context.

A marked income distribution problem is emerging

6 According to the Gini coefficient, a generally accepted international estimation measure, gaps between social incomes are widening. As economic growth has accelerated, differences in income have expanded sharply, especially from region to region, with income levels gradually decreasing as we move across the country from east to west. ${ }^{2}$. Research by Li Peilin and Zhang Yi of the Chinese Academy of Social Sciences (CASS) shows that $20 \%$ of households with the highest income accounted for $38.1 \%$ of the whole income of city and township populations in 1990, with this percentage rising to $43.5 \%$ in 1993 and $52.3 \%$ in $1998^{3}$. So the phenomenon of the Matthew effect induced by the differentiation of poor and rich is becoming increasingly marked, and relative deprivation has already occurred.

The burden coefficient of aged people in China, 1997

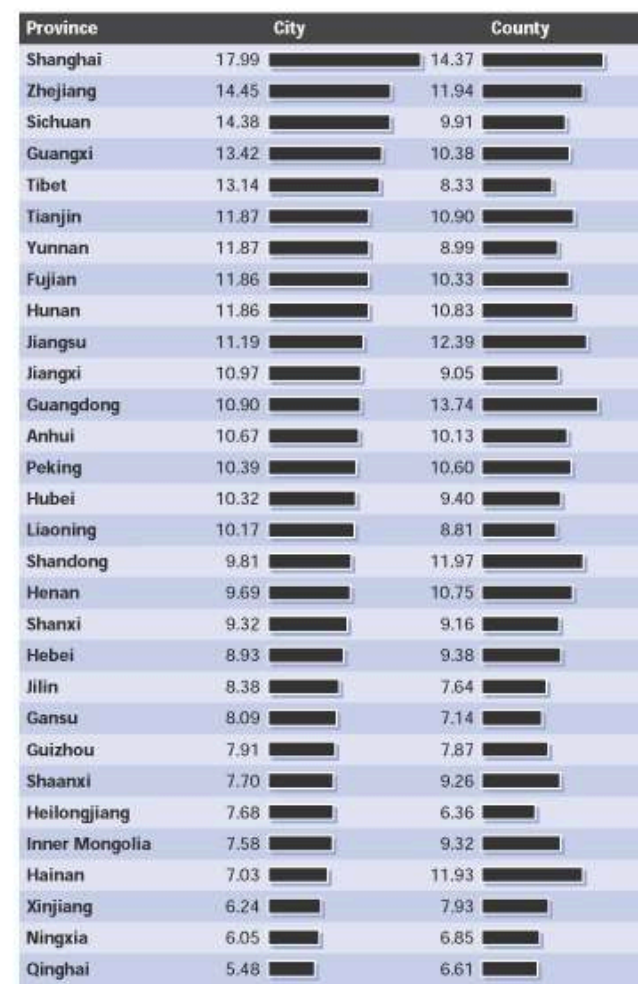

Source: Wang Guojun, « Dui Zhongguo nongcun shehui baoxian tizhi de juxian jiqi gaige de sikao », (The Limitations of the Resident Rural Social Insurance System and Considerations of the Reform) Shanghai shehui kexue yanjiikan (The Quarterly Journal of Shanghai Academy of Social Sciences), $n^{\circ} 1,2000$.

Poverty remains a serious problem in some areas

7 In 1993, the central government launched a project called the “'eight-seven' poverty alleviation reinforcement plan" (which aimed to solve the poverty 


\section{problem of 80 million residents in the whole country within}

7 years from 1993 to 2000). After eight years, China had achieved some good results, but the prospective goals have still not been completely fulfilled. According to a lower evaluation standard, there were still thirty million "poor" people in rural China in 2000. Moreover, with the deepening reform of the state-owned enterprises (SOEs), poverty among urban residents has become very serious. There are two trends embodied in the urban poverty situation: the ratio of the population living in poverty is increasing, while the degree of poverty is worsening every year. The number of poor people in urban China stood at 19.63 million in September $2002^{6}$.

An ageing society

8 In 1999, elderly people accounted for $10.1 \%$ of the total population, which meant that China had become an ageing society. Moreover, China's aged population will enter a period of high growth in the next thirty years. With the explosion of this population, a more solid social safety net is essential. Furthermore, it is important that China's local governments pay more attention to differences between the degree of ageing across the regions (Table 1). A difference also exists between the ageing degrees in urban China and rural China (Table 1). According to one study, the average year in which the 30 provinces (Chongqing is not included) will become part of the ageing society is 2005, and the standard error is 9.36 years. The largest gap between provinces is 36 years?' Increasing marginal groups: a massive floating labour force

9 Since 1978, as a result of the development of non-agricultural industry, the townships and the market, there has been a massive migration of surplus labour from rural areas. According to scholars from different disciplines, the number of unemployed in rural areas has reached at least 200 million. On average, eight million people from rural China entered "township and village enterprises" (xiangzhen qiye) and other non-agricultural activities from 1978 to 1988, while about 10 million people flowed into the towns. Moreover, several million peasants will continue to pour into the cities in the coming years. Importantly, this movement has induced social stratification among people from rural areas, while control has been lost of the social security system in rural China, with great quantities of rural labour in urban China lacking appropriate security. Many among this labour force in urban China have gradually formed marginal groups, called "outliers" (bianyuan qunti), which means that they cannot enjoy citizenship rights in the towns.

With the increase of the frequency of natural disasters, a new relief system is needed China's social and economic development has frequently been interrupted by natural disasters, which also increase social risk. In the view of the World Bank, this will have a damaging effect on the poor in the short term and reduce opportunities to eliminate poverty in the long term. Since 1949, the frequency of natural disasters has increased in China; the affected areas are numerous, and economic losses resulting from the catastrophes are also mushrooming. According to Wang Shaoguang and Hu Angang, 49.24 million hectares of land were affected by natural disasters during the period 1990-1997, with 25 million hectares at the heart of these disasters'. In 1998, the devastating flooding of the Yangtze and Songhua rivers caused major losses for the people there. For a long time, China's traditional disaster relief system featured three characteristics: 1) it depended purely on the central budget finance system; 2) it was based on the collective economy in rural China; and 3) there was no policy for the 
distribution of relief payouts. At present the traditional system is no longer financed from the tongshoutongzhi financial system at the state level, while risk security is not provided adequately by the collective ownership system in rural China. On the whole, a new feasible compensation system is required for victims of disasters. How to prevent, reduce or handle the aftermath of natural disasters has been a major objective of local governments.

Participating in the globalization of the economy and facing international social risks

With its entry into the World Trade Organisation (WTO), China has become a participant in social and economic activity on a global scale. While gaining benefits from this move, China will also face more risks from international society. On the one hand, the peasants will face international competition, and their exposure to market risk will intensify. How to provide a social safety net is a major challenge here. On the other hand, by joining the WTO, China has become an active participant in the flow of human resources and in the division of labour on a global scale. If a system of social security cannot be set up beyond its work units, China's enterprises will be at a competitive disadvantage in relation to their foreign counterparts. Habermas has repeatedly pointed out that the globalisation of an economy affects the sovereign country in ways that will affect the protection of its citizens. How to use the social safety net in economic construction is clearly one key in local government policies for further reform and development.

The reform and innovation of local governments

Social and economic transition has transformed the primary role of government from pure administration to the provision of services. Facing the social problems mentioned above, local governments have been making great efforts to establish and improve the social safety net, especially in the cities. The social security system currently features a basic framework, which includes social relief, social assistance, social welfare, social insurance, and the care of veterans and their families (youfu anzhi). Improvements in three of these areas, including basic unemployment welfare, has been the emphasis of local governments since 1990.

From "work unit welfare" to "the last safety net": the minimum living standard scheme

13 "One experience can be concluded from China's reform practices since the 1980s: successful reform measures tend to originate at the local level" ${ }^{\prime 0}$. A key element of China's social relief system, the "minimum living standard scheme" (zuidi shenghuo baozhang) was set up first in Shanghai in 1993, then later in Xiamen, Qingdao, Dalian, Fuzhou, Guangzhou and Wuxi. These six cities implemented this scheme within the space of about two years, and by 1996 six had become 206. Since September 1997, the minimum living standard scheme in urban China has been extended and enjoyed popularity at a time when the creation and extension of systems was a feature of the organisational behaviour of the national Ministry of Civil affairs (MCA) ${ }^{11}$. Poverty alleviation in urban China was transformed from a moral behaviour to an institutional behaviour.

Based on this, the State Council issued the "Notification concerning the setting-up of a minimum living standard scheme all over the country", in September 1999, which largely promoted the setting-up of organisational systems in another 400 cities. Since then, the minimum living standard scheme in urban areas has entered a phase of management by laws and institutions. By 1999, 2,036 cities and townships had set up 
the system, including four cities directly under the jurisdiction of the central government (zhixiashi), 227 cities at the provincial level (dijishi), 437 cities at the county level (xianjishi) as well as 1,638 townships (zhen).

Currently, most cities and towns have implemented the scheme. By the first half of 1997, a minimum living standard scheme for rural residents had been set up in 1,660 (67\%) cities, counties and districts to the benefit of more than 3.06 million rural residents, a figure that accounted for $0.36 \%$ of the rural population, and by the first half of 1999 the funds invested in these schemes amounted to 366 million yuan. In 2000, the minimum living standard scheme for rural residents made progress: its coverage was expanded and the number of poor people enjoying its benefits reached 3.192 million. The minimum living standard scheme has thus played a positive role in maintaining the social stability of rural China and become a "variation reducing mechanism".

Some studies show that local governments share the same views on the objective of the minimum living standard scheme and the problems that need to be resolved, but that they diverge when it comes to the concrete framework and implementation methods. Some well-known models include those in Shanghai, Wuhan and Chongqing ${ }^{13}$. In the primary phase, each province, district and municipality generally issued notifications of institutional construction for the scheme. In September 1997, local governments started issuing notifications on the progressive institutional construction of and improvements to the scheme. The municipality of Shanghai and the province of Guangdong issued comprehensive laws and regulations on social relief and social assistance: the Shanghai Social Assistance Measures were issued by the Shanghai municipal government, and the Guangdong Social Assistance Ordinance was promulgated by the Guangdong People's Congress ${ }^{14}$.

17 Furthermore, local governments have actively conducted surveys of their areas and have reported good feedback on the local management of the minimum living standard scheme in urban areas. Some local governments have set up top-down social assistance networks and institutional comprehensive assistance models, including social assistance centres in districts and counties, social assistance bureaux at the street level, and the appointment of social assistance co-ordinators on residents committees, and so on. For example, the municipality of Shanghai and the province of Guangdong formed a common way to construct a comprehensive assistance model based on the fundamental needs of the people enjoying the security and on the current financial capacity of governments, and which emphasises the realisation of the siweiyiti (people's livelihood, medical services, education and housing assistance).

By active investigation and improvement, Chinese local governments have gradually set up a management system characterised as "governing by governments, under the responsibility of the civil affairs sectors, collaboration between sectors, implementation at the local grassroots level", and formed an operating system characterised by legitimatisation, socialisation and information ${ }^{15}$.

A basic framework for an unemployment insurance system

In the initial stages of the economic reforms, the central government issued the "Guidelines for the relief of unemployed workers" and the "Temporary measures for the relief of unemployed workers". China's unemployment insurance system only really began in 1986 when the State Council issued the "Temporary regulations on unemployment insurance for employees from state-owned enterprises". After 1990, 
with the establishment and improvement of the market economy system, competition between enterprises intensified, and bankruptcies and job losses (xiagang) followed. In order to solve the problem of fundamental livelihood security for the unemployed population, the State Council issued the "Regulations on unemployment insurance for the employees of SOEs" in 1993. Since then, with the further development of the reform of the SOEs, ideas have gradually changed, and China has accelerated its reform of the unemployment insurance system.

In accordance with central government policy, local governments adjusted the allocation of a part of their funds to ensure fundamental livelihood security for unemployed workers and to provide social insurance. One example of this is the structural adjustments carried out by the municipality of Shanghai in the textile industry. With lay-offs creating the potential for millions of people to become unemployed, the local government amended a number of regulations and measures and in 1995 issued its "Unemployment insurance measures", which adjusted the rising proportion of unemployment insurance fees and regulated the provision standards of its unemployment insurance fund. By 1997, more than 20,000 work units were participating in unemployment insurance schemes, covering more than four million employees, or $92 \%$ of all employees. Another example is provided by Shenzhen, with its new status as a city, where unemployment mainly affects registered permanent residents. As a solution, the Shenzhen government took the following measures: 1) expanded employment opportunities; 2) promoted multiple industries and multiple positions; 3) extended its re-employment project; and 4) changed conceptions of employment and encouraged people to participate in employment training and look for employment opportunities .

In May 1998, the central government increased the fundamental livelihood security of xiagang workers, unemployment insurance, pension insurance, and the minimum living standard scheme. In January 1999, the State Council revised its 1993 "Regulations on the unemployment insurance for the employees of SOEs" and issued the "Regulations on unemployment insurance". This proved the watershed in the establishment of the basic framework of China's unemployment insurance system. It is noticeable that some local governments are expanding the scope of unemployment insurance according to the needs of local reforms and circumstances. Beyond the SOEs, some local governments have provided unemployment insurance for employees of collective enterprises of cities and towns, enterprises invested in by foreign entities, private enterprises, administrative organisations and institutions, and social groups.

On the basis of the innovations in unemployment insurance reform introduced by local governments, the central government, in an advisory note of the Central Committee of the Chinese Communist Party related to the Tenth Five-Year Plan for the National Economy and Social Development, commented on the "further improvement of unemployment insurance, and the input into the fundamental living security of laid-off workers from SOEs into unemployment insurance on the basis of trials". Since 2001, SOEs have begun to abolish the service centres for the re-employment of laid-off workers, and the fundamental living security of laid-off workers (xiagang zhigong) has been amalgamated with unemployment insurance, which means that the original three security lines have now become two. In 2001, laid-off workers from seven coastal provinces with developed economies started receiving unemployment insurance. They exceeded the number of laid-off workers entering re-employment centres, and the re- 
employment rate of laid-off workers began to drop. In order to promote employment, some provincial governments, including those of Liaoning, Heilongjiang and Jiangxi, have issued related policies and measures to add employment to the check-list of government goals.

Furthermore, in Shanghai, Beijing and Jiangsu, shared and part-time or temporary jobs have been developed in order to help disadvantaged groups find jobs in the market system. For instance, the "4050" project in Shanghai aims to help women over forty and men over fifty find re-employment. Recently, the local government in Kunming has taken effective measures to solve re-employment problems among laid-off workers, paying 3.88 million yuan to provide employment positions useful to public interests for xiagang workers. In the future, the local government will do what it can to create about 10,000 valid employment positions and take some measures to reassign more than 7,000 laid-off workers.

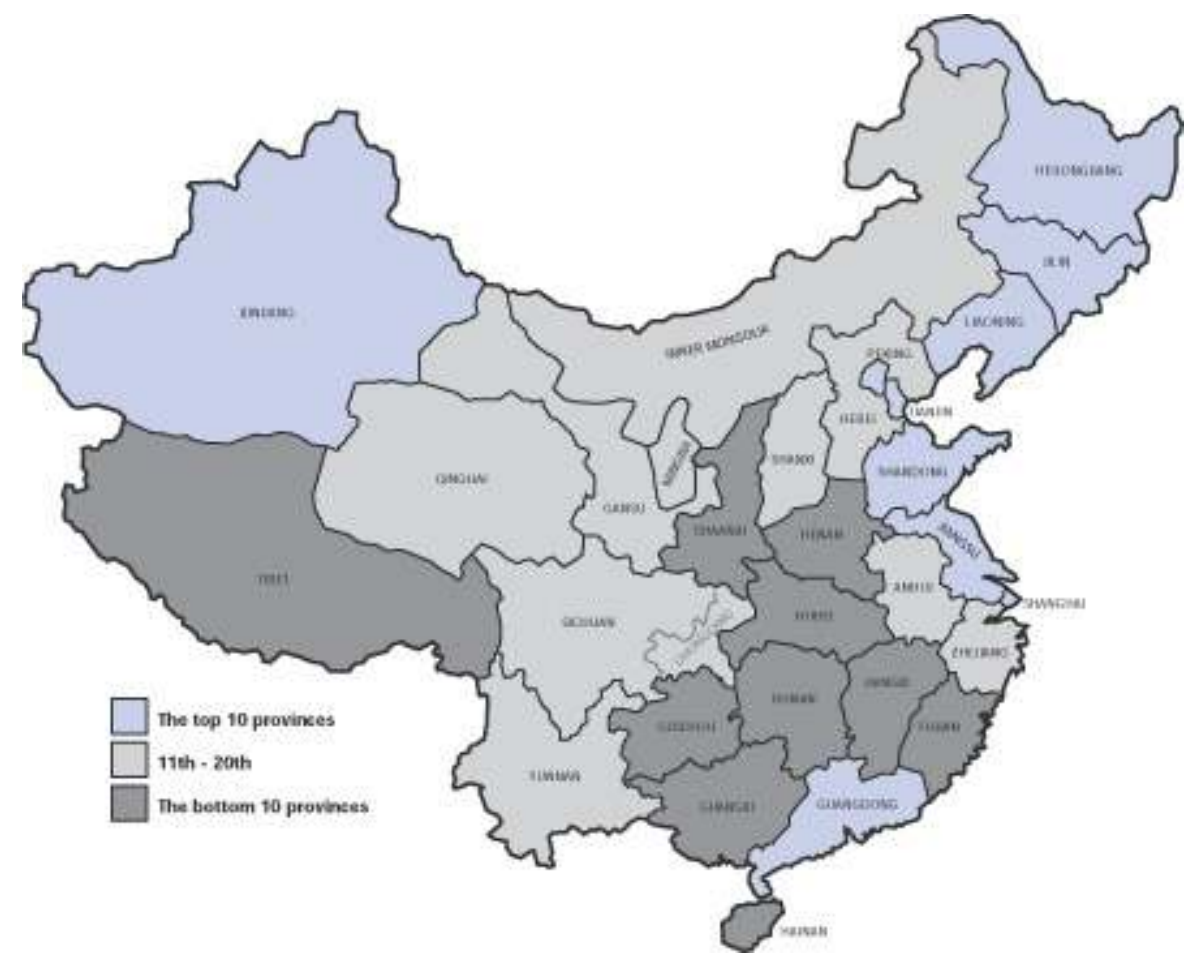

Source: Zhu Qingfang et. al., Shehui baozhang zhibiao tixi (Social Security Index System), Zhongguo shehui kexue chubanshe, 2001.

Facing the ageing problem actively: pension insurance and other measures

Before 1984, Chinese urban pension insurance fell within the framework of the traditional annuity system. In 1984, the crisis enveloping the continuation of this annuity system in some SOEs led the central government to set up a social pooling (shehui tongchou) mechanism to balance the shift in this burden between old and new enterprises. It was in this year that the central government carried out trials in the social pooling of pensions for laid-off workers in five cities and counties in the provinces of Guangdong, Sichuan, Jiangsu and Liaoning. Social pooling was then extended and implemented nationwide. Following further reforms, in 1991 the State Council issued the "Decision on the reform of the pension insurance system for 
enterprise employees". The scope of pensions began to expand, and funds also began to increase. By means of administrative and legal measures, local governments are ensuring that enterprises turn in pension funds adequately and in time.

In 1993, with the encouragement of the central government, local governments developed trial areas so that the payment capacity of the traditional annuity system could be improved, while a framework for the management of social insurance was set up. In view of the facts that the management costs of the employee pension insurance system were too high, that there was a trend towards competition between districts and sectors, and that pension funds were being diverted or misused, the State Council issued its "Notification on further reform of the pension insurance system for enterprise employees" on 1 March 1995. At the same time, it implemented two sets of optional projects for local governments. In the end, local governments devised local interest projects and amended the control rights for surplus pension funds in the short term. Chaos soon reigned. Almost every district had its own project, with the result that pension standards increased in competition with each other among local governments. This caused management and adjustment problems for the central government and made it difficult for employees to change regions.

To establish its authority over the planning of the pension funds and welfare resources, the central government issued the "Decision on the establishment of a united basic pension insurance system for enterprise employees", and thus conceived a mixed pension insurance system that combined social pooling and individual accounts: the partial funding system. In August 1998, the State Council issued its "Notification on relative problems in the transfer of social pooling of basic pension insurance for enterprise employees at the provincial level and trade pooling (hangye tongchou) to local management", which further strengthened the dominant role of the central government in the social security system management mechanism. Since then, the pension insurance system has undergone continuous improvement. In 2000, to modify the combination of social pooling and individual accounts, establish individual accounts that operated using real accounts, and maintain the charging standard of enterprises without increasing the burden on or decreasing the pension level of retired employees, the State Council issued its "trial areas project for the improvement of the social security system in urban China". In 2001, the trials began throughout Liaoning and in one city in the other provinces.

In facing up to the problem of an ageing population, local governments have gained useful experience and implemented measures, among other things to advocate respect for the aged and their rights as well as community help for the aged. The most serious population ageing rate in China can be found in Shanghai, where the government has undertaken numerous initiatives over a number of years to overcome problems of security for the elderly. It has actively promoted the construction of communities where the elderly can obtain services and good health care. Most important in this "community construction" in Shanghai is the culture of respect for the aged. The majority of Shanghai's communities have activity centres for the aged, and the city has also established homes for the elderly and issued laws and regulations to protect the rights of old people.

28 Furthermore, following the example of other countries, some provinces, i.e. Shanghai, Beijing and Jiangsu, have begun to extend the "saving time" system to reflect the local situation. In Shanghai, the Tinan neighbourhood committee started to develop services 
in this field in 1998. In this system, the younger members of the elderly population are organised to provide care services for their older comrades. The service time put in by these "younger old people" is recorded and when they themselves are in need, local governments will organise other younger elderly members to provide them with similar services at least equivalent to the time they have previously put in.

Continuous innovation and a new model of medical security

In the initial stages, China's health security reform emphasised medical insurance reform initiated by the local governments. At that time, under cost pressures, some enterprises introduced innovations for medical security and encouraged the medical security reform by local governments. In November 1985, the Shijiazhuang district of Hebei province began to implement trials in the social pooling of medical fees for retirees. After that, some local governments that were implementing social pooling of pensions also pooled other medical fees. In May 1987, the vegetable company of Beijing's Dongcheng district initiated "Health pooling for serious diseases" (dangbing tongchou), a project that attracted much attention. After the Ministry of Labour and Social Security promoted the trial in a brief report, the labour sectors in Sichuan and Hebei provinces extended this project at the district and county levels or inside general trading companies. Medical insurance reform moved towards socialisation.

The spontaneous reform by local governments received approving nods from the central government, which began medical security system trials under the "Decision on related problems in the establishment of the socialist market economy system". The central government made sure that medical insurance would involve social pooling combined with individual accounts. In September 1994, the State Council empowered Zhenjiang city in Jiangsu province and Jiujiang city in Jiangxi province to carry out the trials, and these two cities issued and implemented the blueprint for China's medical insurance reform. On the basis of their experience, the State Council expanded the trials to fifty-seven cities in April 1996. On the whole, the experimental model, which differed mainly in its concrete approaches to management and work, was adopted. For example, Shenzhen municipal government announced nine related management measures for trial areas in June 1996, before issuing its "Implementing measures for the tentative regulations on the basic medical insurance of Shenzhen" in February 1997 to improve the law and regulation of medical insurance in the city.

31 In 1998, in order to set up the constraint mechanism among hospitals and patients and security and pharmaceuticals sectors, to establish a mechanism for the sharing of the burden of fees, and to ensure that all employees and retirees can receive basic medical services, China launched new reforms of the medical insurance system on the basis of the "Liangjiang" experience. By 2000, a basic medical insurance system had been established for urban employees, with local governments making significant progress in this field.

Dependent on the joint efforts of the central and local governments, medical insurance reform has today entered a new stage as it is extended out nationwide from the trial units. According to research by Tang Xiaolan, the typical reform models mainly include three types: 1) a "mixture", e.g. Shenzhen's plan; 2) "combining the plan as a whole with the individual account", such as that used in the cities of Zhenjiang and Jiujiang; 3) "two existent forms", e.g. in Hainan province".

Poverty problems in rural areas 
33 Although urban poverty is something of a new problem in China, poverty in rural areas has a longer history, and it is prevalent to a far higher degree here than in urban areas. Traditionally, poverty in rural areas was tackled by the establishment of social assistance, which emphasised the family unit within the population (wubaohu). Since 1978, the central and local governments have initiated measures to alleviate poverty in rural China, such as the "Helping the poor project" and, in 1993, the "eightseven' poverty alleviation reinforcement plan" of the central government.

Additionally, local governments have adopted and enforced policies and local regulations as well as, later, organising poor peasants to work in infrastructure construction under the "Replace aid with work" (yigong daichen) project, which not only provides jobs, but also increases the income of poor families. Local governments have also channelled surplus labour in rural areas into developed regions, especially the cities, and have mobilised social initiatives. In most regions, local governments have started up "mutual help"(jieduizi) projects, through which the poor help each other. This involves help with finance, skills, knowledge and technology. During the period from 1997 to 1999, eight million poor people lived by "dressing warmly and eating one's fill by the year". Support granted by the state to poor people in poor counties reduced the population living in poverty from 58.58 million in 1994 to 17.1 million in 2000, thus helping to sustain a balance between progress and stability during the economic development of these areas ${ }^{18}$.

Rural labour in urban areas

35 According to some scholars, Chinese employment policies for rural flows of labour have seen a significant development over the last twenty years. A number of cities along the eastern seaboard have basically fulfilled opening policy plans for peasants in urban areas, particularly in medium or small cities in Guangdong, while many local governments have announced related policies to solve the social security problem among rural labourers in urban China. The local government of Heilongjiang has issued the "Measures for the management of the employment of peasants in urban China in architecture enterprises", which is designed in part to resolve problems of delays in wage payments for rural labourers in urban areas. Furthermore, the municipal government of Peking issued the "Temporary measures on pension insurance for peasants in urban China", a document prescribing that enterprises should provide pension insurance for rural labourers in urban areas, wherever they are from. The governments of Sichuan, Anhui and Xinjiang have also published similar documents.

36 According to relevant ministries, one hundred cities and counties have established 1,000 places where local governments can inspect and measure the flow of surplus rural labour in order to analyse the supply and demand situation and issue timely information to enable its even flow. In some provinces, mainly the experimental regions where local governments are trying their best to establish a sound social security system, newly laid-off workers have not entered re-employment service centres since January $1^{\text {st }} 2001$; they will enjoy unemployment insurance directly. In 2002, in seven provinces with developed economies along the eastern coastal regions, the number of laid-off workers obtaining unemployment insurance had overtaken the number of laid-off workers entering re-employment centres.

Furthermore, Chinese local governments have been investigating disaster relief management mechanisms at different levels-work injury insurance; maternity insurance; social welfare, and so on-which has enabled them to improve the features 
of the social safety net to suit local conditions. For example, in April 1998, the Ministry of Civil Affairs intensified the reforms in trial areas for disaster relief in Liaoning, Zhejiang and Guangdong, with encouraging results.

The inadequacies of local governments

Years of experimentation and trials have produced a basic framework for a social safety net, but many problems still exist: with the framework itself, with its management and operation, and with the relationship among implementing bodies.

Local social safety nets are unsound

China now has a common countrywide understanding concerning the establishment of a social safety net. In the first half of the twenty-first century, China plans to develop a framework for a social security system based on three types of insurance: pension, medical and unemployment. But the establishment of such a net is still recent (with the exceptions of Shanghai and Guangdong, etc.). There are three reasons for this: 1) institutional deficiency; 2) deviations from formal central policies in the behaviour of local governments; 3) the appearance of new types of employment, in particular flexible employment.

Social insurance is mainly designed to solve related problems in urban areas, and there are few programmes for rural residents. The rural social pension plan does not work well, and its coverage is very limited. No new system has been devised to replace the original rural co-operative health security system following its collapse. A great number of poor peasants have difficulty getting to see a doctor and buying medicine. Especially in recent years, the health and medical situation has worsened. Furthermore, the social insurance system mainly covers workers in SOEs and collective enterprises and thus does not provide for all residents, particularly for rural labourers, in urban areas. The limits of institutional arrangements have hindered the social flow of rural labour.

41 Secondly, the establishment of a social safety net has developed unevenly. By mid-2000, almost one-third of Chinese cities had no plans for reforming the medical system, and about 58\% had not carried out any reform. On the one hand, some real difficulties do exist, such as a lack of sufficient funds, experience and competence. On the other hand, some local governments have not carried out a reform of the medical system because local officials do not fully appreciate the significance of establishing a social safety net: their understanding is that decentralised decision-making means there is no need for them to take any action ${ }^{19}$. This makes sense in terms of the differing levels of safety nets required across regions. In a recent study by Zhu Qingfang and her colleagues ${ }^{20}$, twentyfour important social security indices were used to estimate the overall social security level of each province (Table 2). According to their research, the level of social security is high in developed provinces.

The pension system does not recognise planning goals as a whole at provincial level. Two conflicts are clear. The first is that the accumulation of pension funds differs from province to province. By May 1998, accumulated pension funds amounted to 70 billion yuan nationwide. But of this figure, twenty billion yuan can be attributed to Peking, Guangdong, Jiangsu, Shandong, Zhejiang and Shanghai, i.e. about one-third of the total clearly originates mainly from the developed provinces while the contribution from the underdeveloped provinces is minor. The other conflict derives from the first and is due to the uneven development of provinces and cities even at the county level. Within 
several provinces, some regions and cities have accumulated more than one billion yuan, while other regions and cities have defaulted. By the end of May 1998, the value of this default amounted to 8.7 billion yuan, while funds used in other ways or embezzled accounted for 5.56 billion yuan or $63.9 \%$ of the total.

A third point here: as the reforms in urban China deepen, new types of employment, mainly in community services, are emerging. With vast numbers of labourers in need of work, not even created employment is able to absorb them entirely. New types of employment are therefore needed, and flexible jobs are becoming more and more important. Under these circumstances, social security for labourers in flexible jobs cannot be ignored. But because these jobs are temporary, it is difficult for employers to pay social insurance. Accordingly, such employees do not benefit from unemployment, pension or medical insurance.

Fourthly, important problems linked to the transitional process of the implementation of the social security mechanism have still not been resolved. During the period in which pension insurance is transformed from a pay-as-you-go system to one of partial accumulation and individual accounts are adopted, hidden debts are becoming apparent. Empty individual accounts are a characteristic symptom of these hidden debts. Additionally, medical insurance adopts the model that links individual accounts with social pooling, but the concrete proportion and payment scope of individual accounts funds and social pooling funds are also vague, and this is something that should in practice be decided by local governments.

Problems in the management of a social safety net

Local governments also face problems in this area, one of which is represented by the focus group that a social safety net protects. Another is the management of social security funds.

Without any doubt, the unemployed and elderly groups are in urgent need of help. But so are marginal groups. For instance, the identity problem of rural labourers in urban areas needs to be solved. In the long term, the flow of labour from rural areas is inevitable, yet social discrimination is an obstacle to the provision of social security for rural labour in urban areas and requires reconsideration. As mentioned above, some local governments have drawn up policies to solve the problem of social security for rural labour in urban areas, but some have issued policies to limit the flow from rural area.

Furthermore, there is a contradiction between secure fund management and making profits from fund investments. Some local governments have been implementing social safety nets with blank accounts for historical reasons or with local interests in mind. The embezzlement of funds is another major issue.

The relationship between the central and local governments is unsound The economic situation and population differ from province to province, with each province developing at a varying pace since 1978. As a consequence, local governments now have to accept different roles in the establishment of a social safety net.

Local governments have to implement the policies and measures passed down from the central government. Regarding the minimum living standard scheme, the central government requests that "funds of the minimum living standard scheme of urban residents are put into the fiscal budget of local government, to be brought into the special accounts of social assistance funds, special management and usage". On this 
point, the fiscal capacity of local governments determines the level of their lowest provision for living standard security. However, decentralisation has changed the relationship between the central and local governments. Some scholars have called this situation "strong local governments and weak central government". In fact, this description only stresses one aspect of the reality. In many instances, decentralisation has left some regions, especially the poorer provinces, facing financial risks. The development of the southwest for example is slow, and revenues are limited, heavily dependent as they are on subsidies from the central government. In Yunnan province, 120 (or 94\%) of its 128 counties need financial subsidies. The central government thus needs to improve local revenue capacities, especially in taxation. It must also provide financial assistance and policy support to the western regions. Of course, the existence of local interests has also to be taken into account. Under the decentralisation process, some local governments have carried out many policies simply to protect local interests. These problems need to be solved by local governance.

In the light of these difficulties, insufficient institutional innovation is a major reason why some regions are lagging behind. In the 1980s, the eastern regions developed faster because innovative local governments encouraged the development of non-stateowned enterprises. That some localities are straggling is not only due to poor resources, but also a lack of institutional innovation. The attitudes of local governments to this important concept vary widely: some are trying their best to engage in institutional innovation, while others pay it scant attention. As far as health insurance is concerned, some local governments fail to recognise that the supply of basic health insurance depends on local finance and the actual capacity of the enterprises to shoulder the burden. During the reform of medical insurance, these local governments only considered the current requirements. Others continue to lag behind in this area, and the ill-suited approach that they have adopted thus unbalances the overall pace of reform.

From local government to local governance

51 Whether concerning the theory or the practice, the discussion about the model of the Chinese social safety net has raged for a long time. Scholars differ in their opinions. While there are those who think that China should establish one uniform social safety net model, others consider that the model should be multiple. Still others argue that an ideal and sound social safety net would be one of integration and socialisation on multiple levels. Yet others propose that "China should at first transfer the object of social security from one that is governmental to one that is social", and recommend an "adjustment of the income distribution system reflecting the status of different groups and power distribution, and other social security systems by governance and good governance" ${ }^{21}$.

52 In my opinion, the uniform institutional arrangement is best in theory, because it is not only useful for management but is also even-handed. It nevertheless requires strict preconditions, including a developed economy, abundant finance, a similarity of needs across the regions, a balanced regional development, and so on. But these preconditions are absent in China today. As a result, the uniform institution arrangement has to be the long-term objective, and the diverse institution arrangement should be adopted as a transitional objective in the short term. Of course, each single institution, or line, of the social security system can be uniform. 

undertaken from the diverse to the uniform institutional arrangement, including those of policies administrator, direct organiser, and provider, whose aim would be to ensure a policy environment that is fair, stable, convenient and secure throughout people's lives.

Main roles of the Chinese local governments during the transition

Chinese local governments primarily play the following roles in the establishment of a social safety net.

55 As agents of the central government, local governments play an experimental role. Before the central government issues a sound social security policy, it must consolidate the experiences and findings gained from local government trials. The central government will then decide on any further institutional construction. As Xie Yue has pointed out, the increasing difference among the regions has been factored into a mature plan. Failure will not endanger the national economy if the experiment is limited. Furthermore, according to the usual practice before the reforms, the central government also hopes to establish a representative model as the window of reform.

56 Local governments play an enforcement role. After the central government has established a new institution, local governments act as its administrator, organising and implementing the social security system and related policies and raising adequate social security funds. While local governments control the financial resources for the system, they also manage the outcomes. In other words, local governments keep operations effective.

57 Local governments are the sources of institutional innovation. The relationship between the central and local governments is one of mutual co-operation and assistance. Local governments know more about the local situation, so institutional innovations tend to originate here. Since decentralisation, local governments have taken primary responsibility for the security system. Chinese social security reform is a compulsory change, but to some extent it is also a derivational change. The reform of the SOEs is one direct inducement, but the governments do not accumulate adequate funds. Facing these difficulties, local governments have undertaken institutional innovation. According to Western new institutionalism economics, institutional innovations mainly cover three aspects: individuals, volunteer groups, and central government. In other words, local governments are not thought of as the principle innovators in institutional change. Yet they play a very significant role. For instance, Jiangsu province began a reemployment project in 1995, in which all cities and counties now have re-employment service institutions as "one body composed of four social insurances" (siweiyiti), including job introduction and work training, unemployment insurance and labour service centres.

Towards good governance

How to establish a feasible social security model is a global issue, especially in light of the fact that the scarcity of resources at the state level is a worldwide problem. The development trends for social security systems around the world show multiplicity to be a prominent characteristic. During the establishment of a social safety net, more and more actors are coming together to co-operate in and share the obligations of social security-communities, enterprises, households, individuals, central and local 
governments, the tertiary sector, even international society. Among these actors, local governments are important players ${ }^{22}$. First, as a result of changes in social and economic structures, civil society is undergoing a gradual development, with diverse partnerships forming among and between governments and the non-profit and profit sectors in the establishment of a social safety net. As far as China's social security system is concerned, NGOs have played an important role: since the mid-1980s they have organised various kinds of social funds to help the poor to the tune of 50 billion yuan. In May 2001, the central government drafted the "Outline of the poverty reduction plan in helping the poor in rural China (2001-2010)", a document that set forward a poverty reduction strategy for China dominated by the governments but in which social forces will take an active part. Among these social forces, NGOs will participate in the implementation of poverty reduction projects initiated by the various levels of government in order to create new models of poverty reduction and improve their efficiency. Furthermore, with the development of Chinese communities, community services are becoming a new type of social security model ${ }^{23}$. And with the establishment and improvement of modern enterprise institutions, the supplementary security from enterprises has also developed. In the international context, donations and volunteer services have proved important social resources for some countries, developed countries in particular, and constitute an important part of the establishment of social safety nets ${ }^{24}$.

61 Secondly, with intensified social stratification, social heterogeneity has been strengthened. It is not feasible for one single actor to participate in the construction of a social safety net, neither is it appropriate for what a social safety net implies. Whether in theory or in practice, we can observe that it is impossible for governments to take on the burden of the social safety net alone. The term social safety net mainly refers to the policies under which governments provide minimum living standards for the social groups in the greatest difficulty through social relief and social assistance or income support ${ }^{25}$. More importantly, a social safety net requires the active mobilisation of all social resources to provide social protection for people in difficult circumstances. In practice, with the development of social heterogeneity, social resources are scattered among each social segment. In a society facing global risk, the resources in government hands have not proved perfectly capable of providing a social protection system for these people. Governments are trying their best to co-operate with tertiary sectors and market forces; for example, a number of NGOs and communities have participated in the construction of social safety nets. In addition, sectors that are public in some countries are privatised in others.

62 Thirdly, whether in a dichotomy of state and society, or a trichotomy of state, market and society, or in a three dimensional model involving the public sphere, private sphere and the tertiary sector, these models are not able to ensure efficiency and fairness in the distribution of social resources. In economic and sociological terms, this leads to the phenomena called "market failure", "government failure" and "voluntary failure". Obviously, according to the demands imposed by the operation of a social system, the interaction of many actors in co-operation with each other is an effective approach to the resolution of these failures. In recent years, in many countries

China Perspectives, 48 | july- august 2003 
worldwide, especially in developed Western countries, a new public management movement has emerged that includes the reinvention of the public sphere and the reshaping of the public spirit and public finances as a response to the failures mentioned above.

From a world perspective, the globalisation of the economy has brought about profound changes in the administrative environment of each government; every country is looking for new approaches to governance and trying to construct a new and more efficient and responsible model. In China, since 1984, the core of social security reform has been the restructuring of the relationships among the state, enterprises, individuals and society as a way to change the situation in which the enterprises were simply dominant. Eventually, China will set up a new social safety net dominated by society. Henceforth, with the diversity of social economic governance bodies, the construction of a social safety net will need increasing support from communities and enterprises, families, individuals, central and local government, the tertiary sector, even international society. It is therefore my argument that the future model for China's local social safety net, or the strategy choice, will centre on local governments taking on the dominant role in an interaction of multiple players, with the effect that local government is transformed into local good governance, the object of which is to eliminate "social exclusion". Success, and social stability, will therefore depend on the harmonious relationships both between the local governments on the one hand and the central government, the various communities, the enterprises, and individual households on the other, as well as between urban and rural China, and, finally, between the globalisation and the localisation of social policy.

\section{NOTES}

1. Li Shi and Zhao Renwei, "Zhongguo jumin shouru fen peizai yanjiu" (Further Study on the Income Distribution of Chinese Citizens), Jingji yanjiu (Economics study), No. 4, 1999.

2. Zhou Lan, "Zhongguo dangqian jumin shouru de diqu chaju fenxi" (Analysis of the Current Difference of Income of the Habitants among Regions in China), Jiangshan luntan (Jianghan Forum), No. 6, 1997.

3. Li Peilin and Zhang Yi, "Xiaofei fenceng: qidong jingji de zhongyao shidian" (Consumption Stratification: An Important Perspective for Stimulating Economic Development), Zhongguo shehui kexue (China Social Science), No.1, 2000.

4. The "Matthew Effect" is a term coined by Keith Stanovich, a psychologist who has done extensive research on reading and language disabilities, that refers to the idea that in reading (and in other areas of life) the rich get richer and the poor get poorer.

5. Tang Jun, "Zuihou de anquan wang" (The Last Safety Net), Zhongguo shehui kexue, No. 1, 1998, pp. 117-128.

6. Hong Dayong, "Gaige yilai Zhongguo chengshi fupin gongzuo de fazhan licheng" (The Development Process of the Alleviation of Poverty in Urban China since the Reform), Shehuixue yanjiu (Sociology Studies), No. 1, 2003. 
7. Wang Guojun, "Dui Zhongguo nongcun shehui baoxian tizhi de juxian jiqi gaige de sikao" (The Limitations of the Resident Rural Social Insurance System and Considerations of the Reform), Shanghai shehui kexue yuanjikan (The Quarterly Journal of the Shanghai Academy of Social Sciences), No. 1, 2000.

8. Ding Yuanzhu, "Wei shehui buli qunti he ruoshi qunti yiji bianyuan qunti-Gou zhuxin shiqi de shehui anquanwang" (Constructing One Social Protection System for the Socially Disadvantaged, Vulnerable and Marginalised Groups in a New Era), Liaowang (Outlook), No. 16, 2000; Li Qiang, "Chengshi nongmingong de shiye he shehui baozhang wenti" (The Unemployment and Social Security Problem of Rural Labourers in Urban Areas), New Perspective, No. 5, 2001; Zheng Hangsheng, "Shehui pingdeng he shehui fazhan" (Social Equity and Social Development), Jiangsu shehui kexue (Social Science of Jiangsu Province), No. 3, 2001.

9. Hu Angang et. al., Ziran zaihai he jingji fazhan (Natural Disasters and Economic Development), Hubei keji chubanshe, 1998.

10. Tang Jun, “Guanxin zhuanxin qide ruoshi qunti (zhi san)” (Care of Disadvantaged Groups in the Transition [third section]), Zhongguo dangzheng ganbu luntan (Chinese cadre forum of Party and Government), No. 5, 2002.

11. Tang Jun, op. cit., 1998.

12. Duoji Cairang, Zhongguo zuidi shenghuo baozhang zhidu yanjiu he shijian (The Study and Practice of the Chinese Lowest Living Security System), Peking, Renmin chubanshe, October 2001. Duoji Cairang is a former minister of civil affairs in China.

13. Tang Jun, op. cit., 1998.

14. Duoji Cairang, op. cit., 2001.

15. Duoji Cairang, op. cit., 2001.

16. Chen Jiagui ed., Zhongguo shehui baozhang fazhan baogao (1997-2001) (Report on the Development of Social Security, China [1997-2001]), Zhongguo shehui kexue chubanshe, July 2001.

17. Tang Xiaolan, "Dangqian yiliao baoxian moshi de bijiao he xuanze" (Comparison and Choice of the Present Medical Insurance Model), Guangxi shehui kexue, No. 2, 1999, pp. 113-116.

18. Zhongguo zhengfu baipishu 2002 (White Paper of the Chinese Government, 2002), "Zhongguo nongcun fupin kaifa de fazhan" (The Development-oriented Poverty Reduction Program for Rural China), http://www.china.org.cn/ch-book/.

19. Zhang Zuoji, Xinxi ribao (Information Daily), October $1^{\text {st }} 2000$.

20. Zhu Qingfang et. al., Shehui baozhang zhibiao tixi (Social Security Index System), Peking, Zhongguo shehui kexue chubanshe, 2001.

21. Zheng Gongcheng, "Jiaru WTO shenhua shehui baozhang zhidu gaige de xin qiji" (New Turning Point in the Deepening Reform of the Social Security System), Renmin ribao (People's Daily), 3 March 2002; Zheng Gongcheng, “Zhongguo shehui baozhang gaige he zhidu jianshe" (Chinese Social Security Reform and Institutional Construction), Zhongguo renmin daxue xuebao (Journal of Renmin University of China), No. 1, 2003; Zheng Gongcheng, Zhongguo shehui baozhang moshi bianqian jiqi pinggu (Changes in the Chinese Social Security System and Evaluation), Peking, Zhongguo renmin daxue chubanshe, November 2002; Li Yingsheng, "Tansuo Zhongguo shehui baozhang tixi de chengxiang zhenghe zhilu" (Investigating Ways to Integrate Rural and Urban Areas and the Chinese Social Security Model), Zhijiang xuekan (Journal of Zhejiang), No. 5, 2001; Ren Baoping, "Zhongguo shehui baozhang moshi de xuanze jiqi goujian" (Choice and Construction of the Chinese Social Security Model), Academic 
Forum, No. 1, 1998; Lin Shuming, "Jiedu santiao xianzheng he binzhi” (Interpretation of the Co-operating Mechanism of the Three Security Lines), Shehui (Society), No. 2, 2002; Yang Yiyong et al., "Woguo shequ jiuye fazhan zhuangkuang diaocha" (An Investigation regarding the Development of Community Employment in China), Jingji xuejia (The Economist [China]), No. 3, 2001; Yang Tuange Daoshun, “Zhongguo chengshi shequ de shehui huibao zhangxin fanshi: Dalian yu Hangzhou shequ gean yanjiu yu tansuo" (New Type of Social Security from the Urban Community of China-Case Studies from the Community of Dalian and Hangzhou), Guanli shijie (Management World), No. 2, 2002.

22.Yu Keping ed., Zhili he shanzhi (Governance and Good Governance), Peking, Zhongguo shehui kexue wenxian chubanshe, September 2000.

23. Huan Peijun, "Shequ fuwu: yi zhong xinxing shehui baozhang moshi" (Community Services: A New Type of Social Security Model), Hebei daxue chengren jiaoyu xueyuan xuebao (Journal of the Adult Education College of Hebei University), No. 1, 2002; Liu Guizhi, "Tuiguang shequ shehui baozhang de moshi sheji" (Extending the Model of Social Security Derived from Communities), Shuiwu jingji (Tax Affairs Economy), No. 5, 2002.

24. Ding Yuanzhu, "Wei shehui buli qunti he ruoshi qunti yiji bianyuan qunti...", op. cit., Liaowang, 2000; Ding Yuanzhu, Chonggou Zhongguo shehui anquan wang (The Reconstruction of the Social Safety Net in China), Tianjin renmin chubanshe, March 2001.

25. Shang Xiaoyuan, "Zhongguo shehui anquan wang xianzhuang jiqi zhengche xuanze" (The Current Situation of the Chinese Social Safety Net and the Policy Options), Zhanlüe yu guanli (Strategy and Management), No. 6, 2001. 